\title{
Evaluation of High Educational Institutes Economic Impact with Satellite Accounting: An Empirical Application in Greece
}

\author{
Mihail N. Diakomihalis \\ Accounting and Finance Department, Technological Educational Institute of Epirus \\ Psathaki, 48100 Preveza, Greece \\ Tel: 30-268-205-0554 E-mail: diakom@teiep.gr
}

Received: May 28, 2014 Accepted: June 12, 2014

doi:10.5296/ber.v4i2.5852 URL: http://dx.doi.org/10.5296/ber.v4i2.5852

\begin{abstract}
The purpose of this article is to show how to evaluate the various economic impacts generated by the establishment and operation of high educational institutes (HEIs) on a local economy and how HEIs affect the national economy, particularly that of Greece. The methodological framework used in this paper is the Satellite Account for Education (SAE) which has not been yet developed in Greece and therefore consists of a proposed methodological framework based on international human accounting rules and principles. The empirical application concerns the effect of the Technological Educational Institute (TEI) of Epirus on the local economy of the Preveza prefecture through measuring the effect on consumption, GDP, local income, value added tax, and employment. The outcomes of the research are important to the government and education policymakers, especially since Greece faces enormous public finance problems and problems with the transformation of the tertiary education system.
\end{abstract}

Keywords: Economic impact evaluation, Satellite accounting, Public sector, Higher education institutes,

JEL Classifications: E010, H830, I200, M400

\section{Introduction}

Studies focusing on the economic impact evaluation aim to measure the increase in a region's economic activity caused by the establishment and operation of a certain economic 
organization or enterprise (Beck et al, 2006). The degree to which the presence and activity of a Higher Educational Institute (HEI) affects the growth of a regional society and the wider region is mostly of interest to policy-makers at the local and national levels since the presence and operation of institutions stimulates the increase of consumption and production within regions.

The importance of HEIs to regional development is demonstrated in the international and very limited Greek literature. It has become an "accepted fact," proved by public policy-makers who have adopted their regional policies accordingly, that HEIs are significant contributors to regional development [Labrianidis, 2010 (p2011)].

Over the past decades, the need to strengthen regional growth has been a significant criterion in Greece's educational policy concerning the establishment of HEIs. Apart from several descriptive evaluations of the role of universities in regional growth, in-depth research measuring the impact of a higher educational institute on local economies in Greece is extremely limited and does not assess all categories of economic impact.

The role of universities on the growth of Greek regions is figurative not only to researchers but also to all free-minded citizens. They recognized that one of the main reasons for creating regional universities was the conviction based on theory and practice that they contribute to the inversion of some adverse developments and that they will play a decisive role on the growth of the region. Labrianidis [2010 (p.2023)] insists that the Greek government "could adopt other measures in order to exercise regional policy before resorting to the use of universities."

The research aims to determine how effective the selection of a region or specific prefecture is for the establishment of a higher educational institute and the magnitude of the economic boost given to the district or wider area. A prerequisite to that goal is the analysis and evaluation of the economic effects generated by the establishment and operation of HEIs on the local economy; that is the focus of this paper. The case study concerns how two departments of the School of Economics and Management of the Epirus TEI affect the local economy of the region of the Preveza prefecture.

The findings of the research should support policy-makers and the government, especially since Greece now faces enormous problems with regard to interests, conflicts and alliances between organized groups, representatives of influential organizations and state agencies and officials that have transformed the institution of education in Greece into an arena dominated by politics, clientelism and short-term interests.

This paper will present an introduction, followed by the literature review and the approaches of similar research. This section will discuss the Greek experience and allocation policy. The methodology applied is elaborated on extensively in the next chapter. The juxtaposition of the quantitative and qualitative data of Epirus TEI, the paper's case study, follows, along with the procedure and manner of completing the tables of Satellite Accounts for Education (SAE). In the next section, the findings are presented and discussed, including the data and findings tables, and the tables of SAE. 


\section{Literature Review}

Higher Educational Institutes (HEIs) are a natural and important node of regional development (Braunerhjelm, 2008) because they have become increasingly involved in the economic development of several counties. Apart from other effects on the social and economic structure of the region, HEIs also are a factor in economic growth for the region hosting it (Labrianidis, 2010). How much higher education contributes to the regional growth depends on the significance a society attributes to the presence of a HEI in its region (Garlick, 2005).

Higher education's social role and its governing structures have been altered in the past few years to contribute to regional and local needs and interests (Paterson, 2001). The establishment and operation of a HEI has been a key element of regional development policy for many countries because it can affect various processes contributing to the local development directly and indirectly.

The issue of connecting HEIs to the economic growth of regions where the institutes are located has troubled many researchers, with increasing interest in recent years in measuring the impact on regional economies (Drucker and Goldstein, 2007).

The necessity and usefulness of evaluating the effect of a HEI on local economy have become perceptible in countries such as Australia (Garlick, 2005), the islands of the Southern Pacific (Thaman, 2007), Sweden (Duke, 2005), Holland (Raymond, 1992), European countries (Paterson and Lindsay, 2001), Canada (Martin, 1998) and Great Britain (Cox and Taylor, 2006; Bleaney et al., 1992). Drucker and Goldstein (2007) and Bessette (2003) concluded that university activities had "substantially positive results" on the regional economic development of the United States.

Education institutes' expenditures have an impact on the gross domestic product (GDP) through research expenditures and expenditures by students (Martin, 1998) and upon the employment in the region. The assessment of the economic impact of HEIs may be approached by treating a university or TEI as any other business or economic organization, measuring the direct and indirect economic effects poured into a region's economy because of the expenditures associated with the establishment and operation of HEIs. Studies of the impact of a university on the regional economy have not been confined only to backward linkage effects, but also have focused on the forward linkage effects that result from greater engagement with the region's enterprises, revealing that the expansion of the university sector can have great benefit to regional economies, increasing enterprises' sales volume (Cox and Taylor, 2006). Di Veroli and Tartamella (2008) consider the role of government in the process of income redistribution associated with education as another significant element that occurs from the assessment of economic impact of educational institutions. In their impact assessment approach, Bluestone (1993) and Berger and Black (1993) introduced the spillover effects that higher education may have on a region, including effects on human capital, innovation and technology and, consequently the influence on productivity and regional development. The "spillover effect" approach has been adopted by more researchers but disputed by others as overestimating the economic impact of a university or TEI (Brown and Heaney, 1997). Therefore the classical "economic impact approach" will be applied in this study. 


\subsection{The Greek Experience}

The Greek tertiary education system includes all HEIs, including universities and technological educational institutes (TEIs). TEIs are also self-governed legal entities, like the universities, and supported by the state. Their difference from universities is that they are more market and professionally-oriented and linked more directly to the industry and enterprises. TEIs provide theoretical and practical training to enable graduates to adapt easily to a working environment in flux and ever-increasing market demands. The total education cost, including tuition, books and partly food and shelter, is funded by the government. Students' benefits include medical care and reduced fares on public transportation.

New educational institutions should be founded to satisfy the demand for educational services. The reality in Greece was different, priority given to regional development and circumstantially the satisfaction of the demand for educational services. Since the 1960s, Greece has promoted the foundation of regional universities, aiming to enhance regional development. This policy evolved continuous "claims seeking the establishment of a university in almost each city of the above mentioned regions" [Labrianidis, 2010, (p.2016)] serving mainly local interests, interconnected to political parties' benefits.

The establishment of regional universities, i.e., the University of Patras and University of Ioannina, caused significant growth in these regions, expressed mainly with the income and employment increase due to the student and staff population. The universities' contribution to regional development was perceived by Greek society and political parties as a transfer of resources from the state budget to the regions (Labrianidis, 2010).

The considered by the state as successful policy for the intensification of regional development, which has been expressed with the foundation of regional universities since the decade of $60 \mathrm{~s}$, has been chosen by the state to build on for the foundation of regional TEIs.

Even though the contribution of the universities to economic indicators on regional level had not been measured, the achievement of development has been appreciated satisfactory through the increase of population and income, without evaluating the share that is attributed to the educational institutions.

The selection of small or middle-sized cities as the host sites for institutions was prompted by the need for economic reinforcement of the less privileged, less developed areas of the region. The multi-fragmentation of TEIs and their schools in different cities-even though the selection of the cities did not conform to the effectiveness of the educational system in many cases-was grounded in the idea of reducing regional inequalities. It has become an open secret that "the policy of establishing regional universities was mostly the result of political manipulation that aimed at serving the interests of the ruling party, as well as at satisfying the local demand for growth" [(Labrianidis, 2010, (pp.2018-2019)]. The same policy and motives were also applied to the selection of the cities where TEIs were established, without having previously evaluated the expected contribution to the regional growth attributed to the TEI.

The result of the economic reinforcement of the cities selected as hosts for departments or schools of TEIs was similar to that of establishing regional universities that also contributed to 
an increase in income and employment in the region. The attraction of educational and student potential to those regions in parallel with the significant capital invested in infrastructure and equipment prompted an increased demand in goods and services such as housing, food, clothing, transport, communication, entertainment and recreation, strengthening simultaneously many sectors of the economy due to the indirect influences.

This article approaches the evaluation of economic effects attributed to the establishment and operation of a TEI in a specific region in Greece, aiming to contribute to the state and education and regional development policy-makers by revealing the exact economic effects on the local economy and to offer guidance in methodology for future studies on economic impact.

\section{Methodology}

The educational services sector is included in the national accounts of developed countries. The goods connected to this sector such as "school bus services, schoolbooks and supplies, clothing and leisure linked to schools and required by school authorities" are not included in the national accounts [(ONS, 2008, (p. 6)], not allowing the government to evaluate the investment yield from the foundation of educational institutions.

A satellite account will typically involve "activity beyond the production or asset boundary" such as activities not included in the System of National Accounts (SNA). Satellite accounts aim to analyze and explore the significant social and economic activities not distinguished in the SNA. Satellite accounts (SAs) are developed as an expansion of the SNA based on the guidelines of SNA principles. SAs are statistical tools used by national accountants to analyze certain events and their role in the national economy, which cannot be identified or analyzed through normal national accounts.

SA, as suggested by the European System of Accounts (1995), can be developed for many different areas, including tourism, education, research and development, health care, human capital, households, environment and welfare (ONS, 2008; European Commission / Eurostat, 2008; OECD, 2005). A Satellite Account for Education will analyse the education sector and reveal its role in the national economy, contributing to policy making and execution. Financial flows attributed to education shall be entered in the coherent accounts of the SAE to measure the economic effect of financing and producing education.

The education sector includes all teaching activities and subsidiary activities such as "course administration, pedagogical research, general management of education, school and university restaurants, boarding schools, school medical activities, university libraries and the production of pedagogical documents by governmental agencies" [(ONS, 2008, (p.6)]. Expenditures shall be recorded on accrual basis as current consumption comprising individual and collective consumption. The latest corresponds to administrative expenditures of education (Quintela, 2007).

The inclusion of education in the Supply and Uses tables (SU) in the "input-output symmetric table" of the Greek economy and in the table of "gross value added per sector" (NSSG), according to the European System Accounts of 1995 (ESA 95), allows an estimation of the sector's contribution in the most significant macroeconomic indices of the country, since these 
tables include households' final consumption, final consumption of non-profit institutes, final consumption of general government, gross fixed capital formation, changes in inventories, exports, final uses, total uses, imports and duties, domestic production value, intermediate consumption, value added, net taxes on production and imports. As with other sectors, the evaluation of education's economic impact can be attributed by the Supply and Uses tables. The evaluation refers to the whole country and the total expenses included in the direct impacts since typically they cover the total cost of education services provision and include all types of educational and schooling.

Greece has not developed a Satellite Account for Education. Therefore the evaluation of the economic effects on the local and national economies will be attempted with the proposed satellite tables, which were developed based on the 1993 SNA framework of concepts, rules and principles.

The methodology of this paper is based on the SAE framework, but there is not a full SAE compliant since entire economy aggregates are not included as row/column totals, given the focus of the study on a specific educational institute in a particular region. For the selection of the tables required to evaluate the economic impact of education (the Epirus TEI in this case) on the local economy (the Preveza Prefecture), we considered that the producer of education is the public sector. The least required tables are:

SAE 1: Production Account of Education

SAE 2: Value Added of Education and Other Industries

SAE 3: Employment of Education and Other Industries

SAE 4: Consumer Characteristics

In the proposed SAE tables, both the supply and uses are presented on net basis and in current prices. The evaluation of education value added is significant to the development of an ESA. Based on the OECD Methodological Framework of National Accounts SNA93 and ESA95 (Table SAE2), the derivation of education value added is indicated in the following formulas:

$$
E V A i j=(G O i j-I I i j) * E S i j
$$

Where: GOij = Output of the ith commodity from the jth industry.

IIij = Intermediate inputs for the ith commodity of the jth industry.

ESij = Education share of the output of the ith commodity by the jth industry

(which, in most cases, will be the same as the Education ratio for commodity i).

Since the equation $V A j=C E j+G O S j+T P O j$ is valid for any industry

Where: $\mathrm{CEj}=$ Compensation of Employees for the jth industry.

GOSj $=$ Gross Operating Surplus for the jth industry.

TPOj = Taxes less subsidies on Production: Other for the jth industry. 
$\mathrm{VAj}=$ Value Added of the jth industry.

Education Value Added (EVAj) could be alternatively evaluated with the following formula:

$$
E V A j=E C E j+E G O S j+E T P O j
$$

Where: $\mathrm{ECEj}=$ Education Compensation of Employees for the jth industry.

EGOSj = Education Gross Operating Surplus for the jth industry.

ETPOj = Education Taxes less subsidies on Production:Other, for the jth industry.

Knowing EVAj we could estimate any of the following values (as long as it is the only unknown

Value of equation the one we want to estimate): ECEj, EGOSj and ETPOj.

\section{Data-Field Research}

Epirus is considered one of the least developed regions in Greece and European Union as a whole. To date, Epirus appears low on Greece's list of main macroeconomic indicators. Since the greatest impact occurred in smaller regions, universities may be able to act as a substitute for agglomeration economies (Goldstein $\kappa \alpha 1$ Drucker, 2006 and 2007). On these grounds, the case study suits perfectly the purpose of the paper.

In 2008, the Preveza prefecture's gross domestic product amounted to 820 million euro while the gross domestic product per head accounted for $70.8 \%$ of the national average. The GNP ratio of the prefecture compared to the total GNP of the country was $0.4 \%$ (NSSG, 2008). The prefecture is constantly placed below the medial position for most of the economic welfare indicators.

The TEI of Epirus was founded in 1994 and belongs to the technological sector of higher education. Its 15 departments are scattered in all 4 capitals of the Epirus region in northwest of Greece. The Preveza branch includes two departments of the School of Management and Economics (accounting and finance), founded in 1998. The establishment of the institution in this area addresses the politics behind regional development of one of the least developed regions of the country. The lack of regional developmental policy and educational planning led to the selection of Preveza prefecture for the installation of accounting and finance departments. One should not expect the most technological spillovers effects in the area, but this could be taken as a motivation for the approach of this study.

Data presented in Tables 1 and 2 concerning the accounting and finance departments that constitute the Preveza branch of Epirus TEI were collected from the administrative offices of both departments, for the 2008-2009 academic year.

Table 1. Data on Students and Staff of the Preveza branch of Epirus TEI

\begin{tabular}{|l|r|r|r|}
\hline Students & ACCOUNTING & FINANCE & TOTAL \\
\hline Enrolled & 1224 & 670 & 1894 \\
\hline Active Students: $60 \%$ of the total & 569 & 293 & 862 \\
\hline
\end{tabular}




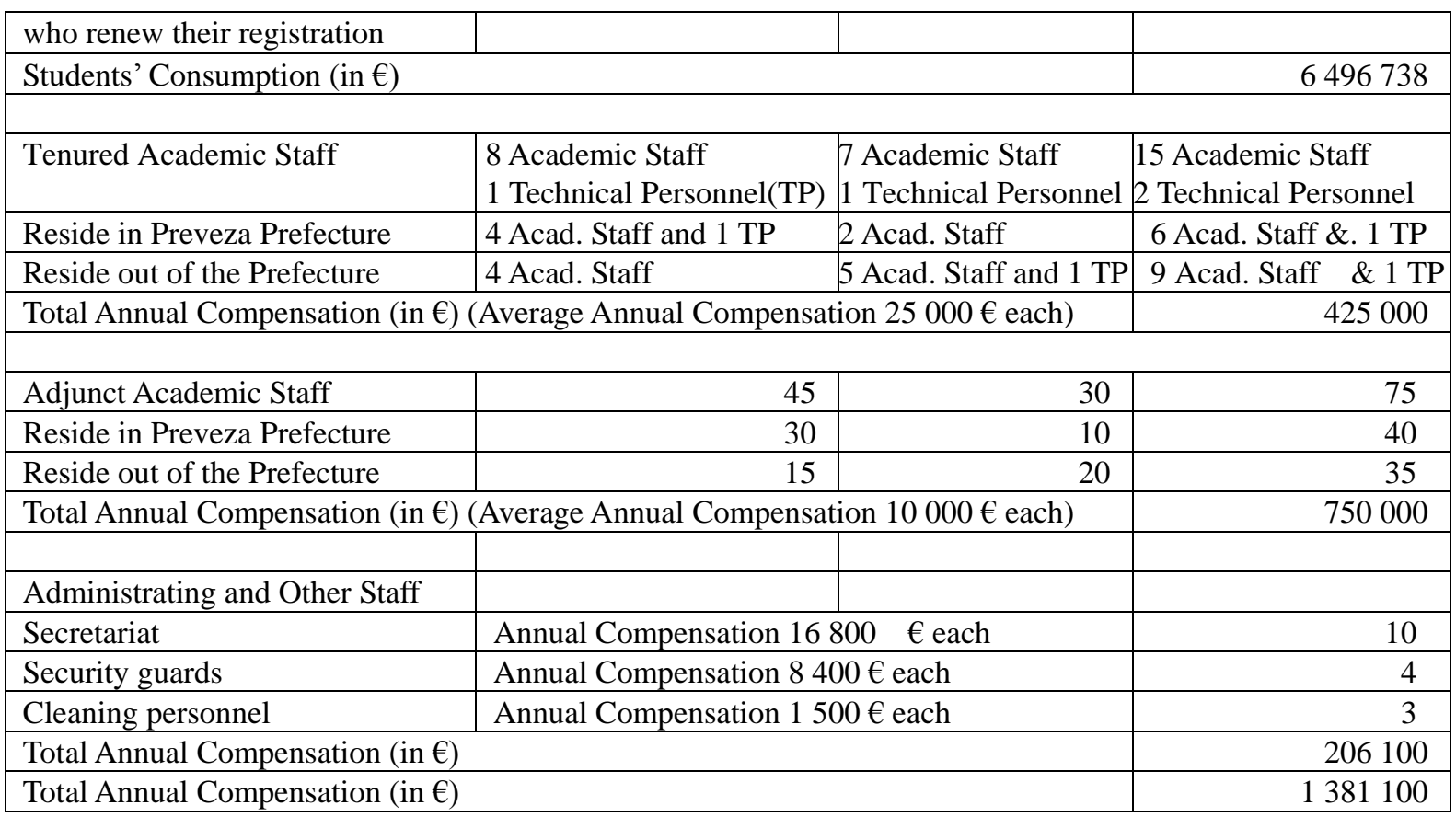

Source: Data from Author's Field research, and Administration office of Preveza Branch of Epirus TEI, 2008-2009.

Table 2. Annual Expenses by cost category for the operation of the Preveza Branch of the Epirus TEI.

\begin{tabular}{|c|c|c|c|}
\hline Expenditure Categories & $\begin{array}{c}\text { Total Expenditure } \\
(1999-2008)\end{array}$ & $\begin{array}{c}\text { Yearly } \\
\text { Expenditure }^{(*)}\end{array}$ & $\begin{array}{c}\text { Expense category for SAE } \\
\text { Tables }\end{array}$ \\
\hline Construction work (Buildings) & $2,500,000$ & 250,000 & Government final Consumption \\
\hline Machinery and Equipment & & 20,000 & Government final Consumption \\
\hline Furniture \& Computers & 300,000 & 30,000 & Government final Consumption \\
\hline $\begin{array}{l}\text { Operating Expenditure (Rent:20.000, } \\
\text { Electricity/ Water / Telephone:30.000) }\end{array}$ & & 50,000 & Government final Consumption \\
\hline Miscellaneous Expenses & & 15.000 & Intermediate consumption \\
\hline Books (for students needs) & & 250,000 & Government final Consumption \\
\hline Paper products (copy paper) & & 35,000 & Intermediate consumption \\
\hline Other Expendable Supplies & & 35,000 & Intermediate consumption \\
\hline Publications (journal) & & 5,000 & Government final Consumption \\
\hline Academic events (Conferences, etc.) & & 15,000 & Government final Consumption \\
\hline Food provision (students alimentation) & & 250,000 & Government final Consumption \\
\hline TOTAL (in $€$ ) & & 955,000 & \\
\hline \multicolumn{2}{|c|}{ TEI EMPLOYEES' COMPENSATION (in €) } & 1381100 & $\begin{array}{l}\text { Value Added of Education } \\
\text { Services of Epirus TEI }\end{array}$ \\
\hline TOTAL ANNUAL EXPENSES (in $€$ ) & & 2336100 & \\
\hline
\end{tabular}

Data concerning students' consumption distribution was collected from 171 questionnaires collected out of the total of 862 active students of the Preveza branch (19.8\%) for the spring 2009 semester, while personnel income distribution was estimated from a sample of 52 out of $109(48 \%)$ full and part time employees at the institute (Tables 3 and 4). 
Table 3. TEI Staff Consumption - Spending by sector.

\begin{tabular}{|l|r|r|}
\hline & Total Staff Compensation (in $€$ ) & Percentage Distribution \\
\hline Rents - Amortization and Interest of housing loans & 392.941 & $28,45 \%$ \\
\hline Electricity Telecommunications Water \& Sewage & 131.797 & $9,54 \%$ \\
\hline Food \& Beverages / Restaurants & 354.964 & $25,70 \%$ \\
\hline Clothing - Footwear- Leather & 102.193 & $7,40 \%$ \\
\hline Entertainment - Recreation & 134.099 & $9,71 \%$ \\
\hline Car Repairs and Maintenance & 175.840 & $12,73 \%$ \\
\hline All other goods and services (Includes Children's tuition) & 89.266 & $6,46 \%$ \\
\hline TOTAL & 1.381 .100 & $100,00 \%$ \\
\hline $\begin{array}{l}\text { From the total expenses, out of Preveza Prefecture is spent 59\% (10/17) of Tenured Academic Staff, and 47\% (35 / 75) of } \\
\text { Adjunct Academic Staff. }\end{array}$ \\
\hline
\end{tabular}

Table 4. Students' Consumption - Spending by sector.

\begin{tabular}{|l|r|r|}
\hline \multicolumn{1}{|c|}{ Consumption distribution } & Annual Expenses (in $€$ ) & Percentage distribution \\
\hline Rents - Amortization and Interest of housing loans* & 2545658 & $39.18 \%$ \\
\hline Electricity Telecommunications Water \& Sewage * & 724080 & $11.15 \%$ \\
\hline Food \& Beverages / Restaurants ** & 833222 & $12.83 \%$ \\
\hline Entertainment - Recreation *** & 900791 & $13.87 \%$ \\
\hline Clothing - Footwear- Leather & 369914 & $5.69 \%$ \\
\hline Books- Publishing and printing services & 121173 & $1.87 \%$ \\
\hline Transportation & 422380 & $6.50 \%$ \\
\hline All other goods and services & 579520 & $8.92 \%$ \\
\hline TOTAL & 6496738 & $100.00 \%$ \\
\hline
\end{tabular}

Source: Author's Field research, 2008-2009

(*) Expenses for "Rents" "Electricity Telecommunications Water \& Sewage" are estimated on a 12 month basis. All other expense categories are estimated on the basis of actual residence of the students in Preveza, which has been evaluated 9 months / year.

$(* *)$ In the expenses categories "Food \& Beverages / Restaurants", "Entertainment - Recreation" and "All other goods and services", have been included visitors expenses, dividing equally the sum of $€ 344800$. (The estimation is based on 862 students, with the $80 \%$ of them having visitors [family members / friends], of average duration 10 days, with average daily expense $€ 50$ ).

$(* * *)$ In the expense category "Entertainment - Recreation" are included expenses for sports, use of internet, cultural and amenities events.

VAT factors in effect for 2008-2009 were the following: 19\% on goods and services, applied only to the intermediate consumption of educational services. For all other industries the factor applied was also 19\%, with the exception of the food and beverages industry, in which both factors (9\% and 19\%) are implied and the factor satisfying the total of the activity is $14 \%$. Books and publishing services were charged with $4 \%$ VAT. For all other goods purchased by staff, administration personnel and students, the mean VAT factor was $14 \%$.

The total and intermediate inputs (at purchaser's prices) of the education services were appraised according to the empirical findings. Value added for education services was 
measured according to the formulas of Satellite Account stated in the methodology section and based on data collected from the empirical research.

Estimates of total output and intermediate inputs for all other industries were based on the technological factors of the most recent symmetric input/output tables of the National Statistics Services of Greece (NSSG, 2005). Most of the transactions recorded in the "Supply and Use" tables of the National Accounts are represented in purchaser's prices. To estimate transactions in basic prices for TSA Tables 1 to 3, trade and transport margins, deductible VAT and net taxes on production: other were deducted from the purchaser's prices. The tax rates for various industries are available in the tax legislation in effect.

The number of employees in the TEI of Preveza was estimated according to the empirical research, while the evaluation of workers in other industries was based on tables "Employees by economic sector" and "Supply and Uses" for 2008 (NSSG, 2008). The outcome resulted from combined calculations of the tables above. Since hours of employment gives a better indication of how much labor was required to produce a given amount of output than "jobs," the number of hours worked was measured on the ground that full employment was 48 weeks/year, 5 days/week and 8 hours/day (1 920 hours). The total and average expenditures have been estimated in purchaser's prices (include VAT, retail/wholesale and transport margins, net taxes on products or production).

The trade and transport margins concern only the goods and not the services. These were based on the factors of the Supply and Uses Tables (2008) of the National Statistical Service of Greece. The percentages of imports for each category of goods are derived from the same tables.

\section{Final Results}

The total consumption attributed to TEI in Preveza is $€ 2336$ 100; the consumption made up of personnel is $€ 1381100$ and that of students is $€ 6496740$. The total consumption by all those involved in the educational process (institute, staff, students) is $€ 10213940$ (SAE Table 2 and 4). The mean spending of the institute per student is $€ 2710.10$ per year and the average personnel consumption is $€ 24662.50$ per year, while the average per student spending is $€ 7$ 536.82 per year (SAE Table 4).

A significant finding is the structure of consumption per sector, as expressed in Tables 2, 3 and 4 and SAE Table 4 . The different spending patterns and consuming needs between TEI staff and personnel on one hand and students on the other are retrieved.

The estimation of value added at purchasers' prices, which also constitutes the regional product attributed to education activity, is identified with the effect on the region's gross domestic product. The operation of the Preveza branch of the Epirus TEI contributed $€ 7536470$ to the GDP of the prefecture in 2008. A little more than 60\% (€ 4724970$)$ is attributed to students consumption, $25 \%$ is attributed to the spending of the TEI itself and the remaining $12 \%$ to personnel consumption (Table 5, Figure 1, and SAE Tables 1 and 2). 


\section{Ml Macrothink}

Business and Economic Research

ISSN 2162-4860

2014, Vol. 4, No. 2

Table 5. Estimation of Education Gross Regional Product of the Prefecture (.000€)

\begin{tabular}{|l|r|r|r|r|}
\hline \multicolumn{1}{|c|}{ Activity “industry” } & \multicolumn{1}{|c|}{$\begin{array}{c}\text { Epirus TEI } \\
\text { (Preveza } \\
\text { Branch) }\end{array}$} & $\begin{array}{l}\text { Personnel } \\
\text { Consumption }\end{array}$ & $\begin{array}{l}\text { Students } \\
\text { Consumption }\end{array}$ & $\begin{array}{c}\text { Total Value } \\
\text { Added }\end{array}$ \\
\hline $\begin{array}{l}\text { Education Services of Epirus TEI } \\
\text { (Preveza Branch) }\end{array}$ & $1.381,10$ & & & $1.367,53$ \\
\hline All other commodities consumed & 407,16 & 796,31 & $4.193,45$ & $5.396,91$ \\
\hline Value Added (at basic values) & $1.788,26$ & 796,31 & $4.193,45$ & $6.778,01$ \\
\hline Net Taxes on Production & 85,53 & 141,40 & 531,53 & 758,46 \\
\hline GDP at purchasers' prices & $2.336,10$ & 937,71 & $4.724,97$ & $7.536,47$ \\
\hline
\end{tabular}

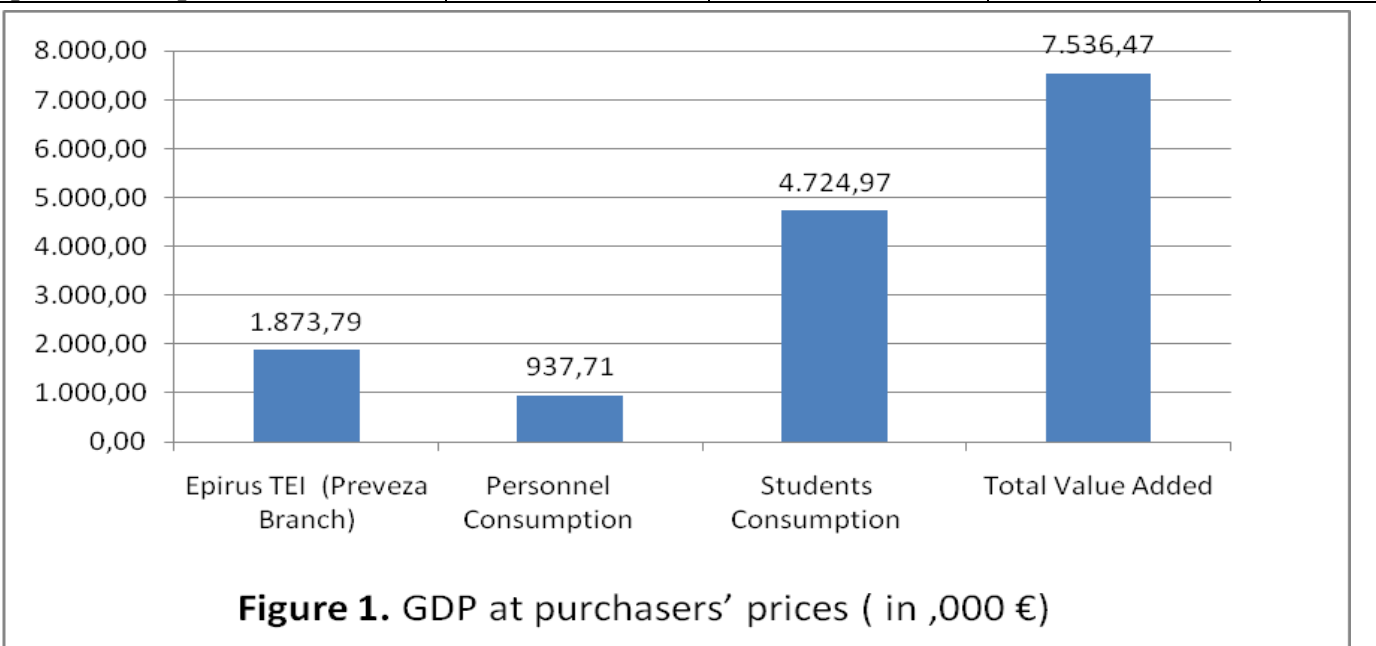

According to official data, the per capita GDP of the prefecture for 2008 (www.economics.gr) was $€ 14$ 300. Considering that the population of the last census (NSSG, 2011) was 57,700 inhabitants, we conclude that the participation of the TEI operation in the GDP of the prefecture corresponds to $€ 130.62$ per inhabitant, slightly below $1.0 \%$ of the total GDP.

Table 6 presents the effect of the operation of the TEI in Preveza on the gross local income, found by adding the income created by the institute's consumption and that of its personnel and students and deducting the part of these expenditures paid out of the prefecture. The local income created because of the operation of the TEI and spent within the prefecture was an estimated $€ 9205$ 690, which is approximately $9 \%$ of the total declared income of the Preveza prefecture (Table 6, Figure 2).

Table 6. Gross Local Income generated in Preveza Prefecture (in .000 €)

\begin{tabular}{|l|r|r|r|r|}
\hline \multicolumn{1}{|c|}{$\begin{array}{c}\text { Activity } \\
\text { "industry" }\end{array}$} & $\begin{array}{c}\text { Epirus TEI } \\
\text { (Preveza Branch) }\end{array}$ & $\begin{array}{l}\text { Personnel } \\
\text { Consumption }\end{array}$ & $\begin{array}{l}\text { Students } \\
\text { Consumption }\end{array}$ & Total \\
\hline Expenditures -Consumption & 2336.10 & 1381.10 & 6496.74 & 10213.94 \\
\hline $\begin{array}{l}\text { Less: Expenditures for Assets and } \\
\text { Equipment paid out of the Prefecture }\end{array}$ & $-150.00^{*}$ & & & -150.00 \\
\hline $\begin{array}{l}\text { Less: Operational Expenditures paid out } \\
\text { of the Prefecture }\end{array}$ & $-255.00^{* *}$ & $-603.25 * * *$ & & $-858,25$ \\
\hline & $1.931,10$ & 777,85 & $6.496,74$ & $9.205,69$ \\
\hline
\end{tabular}

*(Data from Table 4, used also in Table 6) 50\% of the total of "Construction work" (250 000), Machinery and Equipment (20 000) and "Furniture \& Computers" (30 000), are paid out of the Preveza prefecture. 
** Expenditures for "Books" (250 000) and "Publications" (5 000), are paid out of the Preveza prefecture

*** TEI Personnel Expenditures paid out of the Preveza prefecture $(425000 \mathrm{X} 59 \%)+(750000 \mathrm{X} 47 \%)=603$ 250

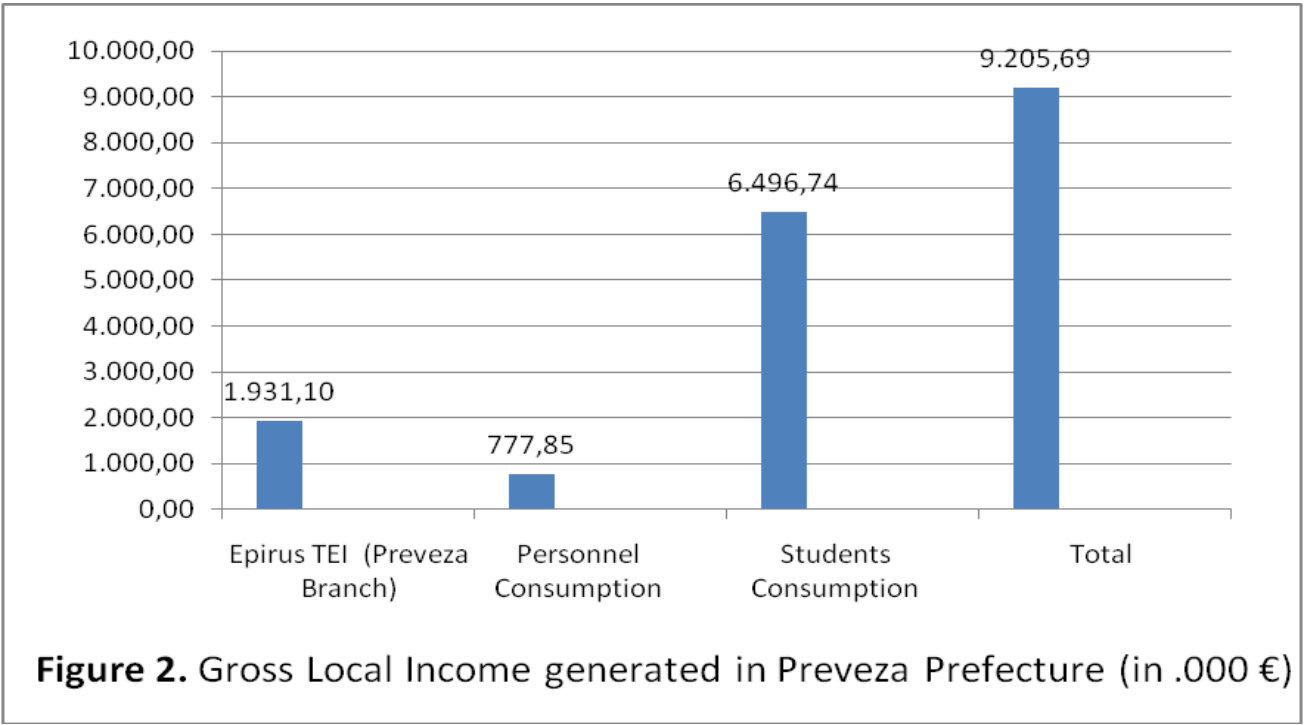

Direct employment in the institute includes 17 tenured academic staff, 75 adjunct academic staff, 10 secretarial personnel, 4 security personnel and 3 cleaning personnel (Table 1). Since not all employees work full time, part time jobs are converted to their full-time equivalent (FTE) or to annual total hours worked. The adjunct academic staff equals 24 FTE jobs, while the cleaning staff is estimated to correspond to 1 full time job. Therefore, the total direct FTE labour is an estimated 56 jobs $(17+10+4+1+24)$.

The employment created by the production and consumption of "all the other goods and services" consumed for education needs is estimated based on the index employment/domestic production per sector according to the data of the National Statistical Service of Greece (see Tables of "Supply and Uses" and Table NSSG "Employed persons per one-digit categories of economic activity, 2008). This indirect employment totals 96 FTE jobs. Therefore the operation of the Epirus TEI in the Preveza prefecture attributes a total of 152 jobs (SAE Table 3). There are approximately 19464 employed inhabitants of the prefecture, since $83.17 \%$ of the $40.25 \%$ of the active population is employed. Consequently, the Epirus TEI, with 152 employment positions necessary for its operation, contributes by $0.78 \%$ in the total employment of the prefecture (SAE Tables 1 and 3).

The estimation of value added tax (VAT) includes VAT imposed on all goods and services required for the education sector as well as all other goods and services consumed by the institute and its personnel and students (Table 7 and SAE Table 2).

Table 7. Value Added Taxes, by Consumer category and total (.000€)

\begin{tabular}{|r|r|r|r|}
\hline Epirus TEI (Preveza Branch) & Personnel Consumption & Students Consumption & Total VAT \\
\hline 85.53 & 141.40 & 531.53 & 758,46 \\
\hline
\end{tabular}

The state revenue offices (concerning the VAT) can expect an annual increase of their income by $€ 758460$ as a result of the institute's consumption and that of its staff and students. 


\section{Macrothink}

Business and Economic Research

ISSN 2162-4860

5.1 Satellite Accounts for Education (SAE) Tables 1-4

2014, Vol. 4, No. 2

SAE Table 1. Satellite Account for Education 1, Production Account of Education (Current Prices) (in .000 €)

\begin{tabular}{|c|c|c|c|c|c|c|c|c|c|c|c|c|c|c|c|c|}
\hline $\begin{array}{l}\text { Characteristic Industries } \\
\\
\text { Output (at basic prices) } \\
\text { Characteristic commodities }\end{array}$ & $\begin{array}{l}\text { Educatio } \\
\mathrm{n}\end{array}$ & $\begin{array}{l}\text { Confer } \\
\text { ences }\end{array}$ & $\begin{array}{l}\text { Real } \\
\text { Estate- } \\
\text { Housing }\end{array}$ & $\begin{array}{l}\text { Electricit } \\
\text { y } \\
\text { Telecom } \\
\text { municati } \\
\text { ons } \\
\text { Water \& } \\
\text { Sewage }\end{array}$ & $\begin{array}{l}\text { Restaura } \\
\text { nts }\end{array}$ & $\begin{array}{l}\text { Constr } \\
\text { uction } \\
\text { work }\end{array}$ & $\begin{array}{l}\text { Machi } \\
\text { nery } \\
\text { and } \\
\text { equipm } \\
\text { ent }\end{array}$ & $\begin{array}{l}\text { Food } \\
\& \\
\text { Bevera } \\
\text { ges }\end{array}$ & $\begin{array}{l}\text { Transp } \\
\text { ortation }\end{array}$ & $\begin{array}{l}\text { Clothin } \\
\mathrm{g} \quad- \\
\text { Footwe } \\
\text { ar- } \\
\text { Leather }\end{array}$ & $\begin{array}{l}\text { Enterta } \\
\text { inment } \\
\text { - Clubs }\end{array}$ & $\begin{array}{l}\text { Books, } \\
\text { paper } \\
\text { products } \\
; \\
\text { publishi } \\
\text { ng / } \\
\text { printing } \\
\text { services }\end{array}$ & $\begin{array}{l}\text { Repairs } \\
\text { and } \\
\text { Maintena } \\
\text { nce } \\
\text { Services }\end{array}$ & $\begin{array}{l}\text { All } \\
\text { other } \\
\text { goods } \\
\text { and } \\
\text { service } \\
\text { s }\end{array}$ & $\begin{array}{l}\text { Wholesa } \\
\text { le and } \\
\text { retail } \\
\text { trade } \\
\text { services }\end{array}$ & $\begin{array}{l}\text { Total } \\
\text { Domestic } \\
\text { Supply }\end{array}$ \\
\hline $\begin{array}{l}\text { Education Services of Epirus TEI } \\
\text { (Preveza Branch) }\end{array}$ & $1.466,10$ & & & & & & & & & & & & & & & $1.466,10$ \\
\hline $\begin{array}{l}\text { Rents - Amortization and Interest of } \\
\text { housing loans }\end{array}$ & & & 20,00 & & & & & & & & & & & & & 20,00 \\
\hline $\begin{array}{l}\text { Electricity Telecommunications Water } \\
\& \text { Sewage }\end{array}$ & & & & 25,21 & & & & & & & & & & & & 25,21 \\
\hline Books & & & & & & & & & & & & 192,31 & & & & 192,31 \\
\hline Publishing services & & & & & & & & & & & & 3,85 & & & & 3,85 \\
\hline Conferences & & 12,61 & & & & & & & & & & & & & & 12,61 \\
\hline Restaurants & & & & & 229,36 & & & & & & & & & & & 229,36 \\
\hline Construction work & & & & & & 210,08 & & & & & & & & & & 210,08 \\
\hline Machinery and equipment & & & & & & & 25,21 & & & & & & & & & 25,21 \\
\hline Repairs and Maintenance & & & & & & & & & & & & & 16,81 & & & 16,81 \\
\hline $\begin{array}{l}\begin{array}{l}\text { Retail, Wholesale \& } \\
\text { Margins }\end{array}\end{array}$ & & & & & & & & & & & & & & & 49,04 & 49,04 \\
\hline $\begin{array}{l}\text { Total Output of Characteristic goods of } \\
\text { Epirus TEI (Preveza Branch) }\end{array}$ & $1.466,10$ & 12.61 & 0.00 & 0.00 & 229.36 & 210,08 & 25,21 & 0,00 & 0,00 & 0,00 & 0,00 & 196,15 & 16,81 & 0,00 & 49,04 & $2.250,57$ \\
\hline \multicolumn{17}{|c|}{ Output (at basic prices) of goods consumed by staff and other personnel (in.000 $€$ ) } \\
\hline $\begin{array}{l}\text { Rents - Amortization and Interest of } \\
\text { housing loans }\end{array}$ & & & 392,94 & & & & & & & & & & & & & 392,94 \\
\hline $\begin{array}{l}\text { Electricity Telecommunications Water } \\
\& \text { Sewage }\end{array}$ & & & & 110,75 & & & & & & & & & & & & 110,75 \\
\hline Restaurants & & & & & 62,27 & & & & & & & & & & & 62,27 \\
\hline Food \& Beverages & & & & & & & & 193,10 & & & & & & & & 193,10 \\
\hline
\end{tabular}




\section{Macrothink}

Business and Economic Research

ISSN 2162-4860

\begin{tabular}{|c|c|c|c|c|c|c|c|c|c|c|c|c|c|c|}
\hline Transportation & & & & & & & & & & & & & & 0,00 \\
\hline Clothing - Footwear- Leather & & & & & & & & 44,50 & & & & & & 44,50 \\
\hline Entertainment - Recreation & & & & & & & & & 112,69 & & & & & 112,69 \\
\hline Repairs and Maintenance & & & & & & & & & & & 147,76 & & & 147,76 \\
\hline All other goods and services & & & & & & & & & & & & 63,92 & & 63,92 \\
\hline $\begin{array}{l}\text { Total Retail, Wholesale \& Transport } \\
\text { Margins }\end{array}$ & & & & & & & & & & & & & 111,76 & 111,76 \\
\hline $\begin{array}{l}\text { Total production consumed by staff } \\
\text { and other personnel }\end{array}$ & 0.00 & 0.00 & 392,94 & 110,75 & 62,27 & 193,10 & 0,00 & 44,50 & 112,69 & 0,00 & 147,76 & 63,92 & 111,76 & $1.239,70$ \\
\hline
\end{tabular}

Output (at basic prices) of goods consumed by students (in .000 $€$ )

\begin{tabular}{|c|c|c|c|c|c|c|c|c|c|c|c|c|c|c|c|c|}
\hline $\begin{array}{l}\text { Rents - Amortization and Interest of } \\
\text { housing loans }\end{array}$ & & & 2545.66 & & & & & & & & & & & & & 2545.66 \\
\hline $\begin{array}{l}\text { Electricity Telecommunications Water } \\
\& \text { Sewage }\end{array}$ & & & & 608.47 & & & & & & & & & & & & 608.47 \\
\hline Restaurants & & & & & 365.45 & & & & & & & & & & & 365.45 \\
\hline Food \& Beverages & & & & & & & & 283.29 & & & & & & & & 283.29 \\
\hline Transportation & & & & & & & & & 387.50 & & & & & & & 387.50 \\
\hline Clothing - Footwear- Leather & & & & & & & & & & 161.06 & & & & & & 161.06 \\
\hline Entertainment - Recreation & & & & & & & & & & & 756.97 & & & & & 756.97 \\
\hline Books, newspapers, magazines & & & & & & & & & & & & 93.21 & & & & 93.21 \\
\hline All other goods and services & & & & & & & & & & & & & & 414.98 & & 414.98 \\
\hline $\begin{array}{l}\text { Total Retail, Wholesale \& Transport } \\
\text { Margins }\end{array}$ & & & & & & & & & & & & & & & 348.62 & 348.62 \\
\hline $\begin{array}{l}\text { Total production consumed by } \\
\text { students }\end{array}$ & 0.00 & 0.00 & 2545.66 & 608.47 & 365.45 & & & 283.29 & 387.50 & 161.06 & 756.97 & 93.21 & 0.00 & 414.98 & 348.62 & 5965.21 \\
\hline Total production (at basic prices) & $1.466,10$ & 12,61 & $2.958,60$ & 744,43 & 657,08 & 210,08 & 25,21 & 476,39 & 387,50 & 205,56 & 869,66 & 289,36 & 164,57 & 478,90 & 509,42 & $9.455,48$ \\
\hline $\begin{array}{l}\text { Intermediate consumption (at } \\
\text { purchaser's prices) }\end{array}$ & 85,00 & 1,37 & 422,49 & 307,38 & 276,57 & 107,58 & 15,15 & 353,86 & 125,05 & 119,72 & 261,42 & 175,38 & 49,47 & 174,80 & 202,24 & $2.677,47$ \\
\hline Value Added (at basic prices) & $1.381,10$ & 11,24 & $2.536,11$ & 437,06 & 380,52 & 102,50 & 10,06 & 122,53 & 262,46 & 85,84 & 608,24 & 113,98 & 115,10 & 304,10 & 307,18 & $6.778,01$ \\
\hline Number of employees & 51 & 0 & 30 & 6 & 9 & 3 & 0 & 5 & 5 & 2 & 16 & 3 & 2 & 7 & 11 & 150 \\
\hline
\end{tabular}


SAE Table 2. Satellite Account for Education 2, Value Added of Education \& Other Industries (in .000€)

\begin{tabular}{|c|c|c|c|}
\hline $\begin{array}{l}\text { Output (at basic prices) } \\
\text { Characteristic commodities }\end{array}$ & $\begin{array}{c}\text { Output } \\
\text { (at basic prices) }\end{array}$ & $\begin{array}{c}\text { Intermediate } \\
\text { Consumption } \\
\text { (at purchaser's prices) }\end{array}$ & $\begin{array}{l}\text { Education } \\
\text { Value Added }\end{array}$ \\
\hline Education Services of Epirus TEI (Preveza Branch) & $1.466,10$ & 85,00 & $1.367,53$ \\
\hline Rents - Amortization and Interest of housing loans & 20,00 & 2,86 & 17,14 \\
\hline Electricity Telecommunications Water \& Sewage & 25,21 & 10,41 & 14,80 \\
\hline Books & 192,31 & 116,56 & 75,75 \\
\hline Publishing services & 3,85 & 2,33 & 1,52 \\
\hline Conferences & 12,61 & 1,37 & 11,24 \\
\hline Restaurants & 229,36 & 96,54 & 132,82 \\
\hline Construction work & 210,08 & 107,58 & 102,50 \\
\hline Machinery and equipment & 25,21 & 15,15 & 10,06 \\
\hline Repairs and Maintenance & 16,81 & 5,05 & 11,76 \\
\hline Retail, Wholesale \& Transport Margins & 49,04 & 19,47 & 29,57 \\
\hline $\begin{array}{l}\text { Total Output of Characteristic goods of Epirus TEI } \\
\text { (Preveza Branch) }\end{array}$ & $2.250,57$ & 462,31 & $1.788,26$ \\
\hline \multicolumn{4}{|c|}{ Output (at basic prices) of goods consumed by staff and other personnel ( in .000 $€$ ) } \\
\hline Rents - Amortization and Interest of housing loans & 392,94 & 56,11 & 336,83 \\
\hline Electricity Telecommunications Water \& Sewage & 110,75 & 45,73 & 65,02 \\
\hline Restaurants & 62,27 & 26,21 & 36,06 \\
\hline Food \& Beverages & 193,10 & 143,43 & 49,66 \\
\hline Clothing - Footwear- Leather & 44,50 & 25,91 & 18,58 \\
\hline Entertainment - Recreation & 112,69 & 33,87 & 78,81 \\
\hline $\begin{array}{l}\text { Repairs and Maintenance (includes Transportation } \\
\text { means) }\end{array}$ & 147,76 & 44,42 & 103,35 \\
\hline All other goods and services & 63,92 & 23,33 & 40,59 \\
\hline Total Retail, Wholesale \& Transport Margins & 111,76 & 44,37 & 67,39 \\
\hline Total production consumed by staff \& personnel & $1.239,70$ & 443,39 & 796,31 \\
\hline \multicolumn{4}{|c|}{ Output (at basic prices) of goods consumed by students (in .000 €) } \\
\hline Rents - Amortization and Interest of housing loans & 2545.66 & 363.52 & 2182.14 \\
\hline Electricity Telecommunications Water \& Sewage & 608.47 & 251.24 & 357.23 \\
\hline Restaurants & 365.45 & 153.82 & 211.63 \\
\hline Food \& Beverages & 283.29 & 210.43 & 72.86 \\
\hline Transportation & 387.50 & 125.05 & 262.46 \\
\hline Clothing - Footwear- Leather & 161.06 & 93.80 & 67.26 \\
\hline Entertainment - Recreation & 756.97 & 227.54 & 529.42 \\
\hline Books, newspapers, magazines & 93.21 & 56.49 & 36.72 \\
\hline All other goods and services & 414.98 & 151.47 & 263.51 \\
\hline Total Retail, Wholesale \& Transport Margins & 348.62 & 138.40 & 210.22 \\
\hline Total production consumed by students & 5965.21 & 1771.76 & 4193.45 \\
\hline Total production (at basic prices) & $9.455,48$ & $2.677,47$ & $6.778,01$ \\
\hline VAT (Characteristic industries) & 85,53 & & 85,53 \\
\hline VAT (all other goods consumed by personnel) & 141,40 & & 141,40 \\
\hline VAT (all other goods consumed by students) & 531,53 & & 531,53 \\
\hline Total Output and Value Added (Purchaser's prices) & $10.213,94$ & & $7.536,47$ \\
\hline
\end{tabular}




\section{Macrothink}

Business and Economic Research

ISSN 2162-4860

2014, Vol. 4, No. 2

SAE Table 3. Satellite Account for Education 3, Employment of Education and Other Industries

\begin{tabular}{|c|c|c|c|c|}
\hline Characteristic Industries & $\begin{array}{l}\text { Number of } \\
\text { employees }\end{array}$ & $\begin{array}{c}\text { Other } \\
\text { Employment }\end{array}$ & $\begin{array}{c}\text { Total } \\
\text { employment }\end{array}$ & $\begin{array}{c}\text { Total hours } \\
\text { (in ,000) }\end{array}$ \\
\hline Education Services of Epirus TEI (Preveza Branch) & 51 & 5 & 56 & 107520 \\
\hline Real Estate - Housing & 30 & & 30 & 57600 \\
\hline Electricity Telecommunications Water \& Sewage & 6 & & 6 & 11520 \\
\hline Books - Publishing services & 3 & & 3 & 5760 \\
\hline Conferences & 0 & & 0 & 0 \\
\hline Restaurants & 9 & & 9 & 17280 \\
\hline Food \& Beverages & 5 & & 5 & 9600 \\
\hline Transportation & 5 & & 5 & 9600 \\
\hline Clothing - Footwear- Leather & 2 & & 2 & 3840 \\
\hline Entertainment - Recreation & 16 & & 16 & 30720 \\
\hline Repairs and Maintenance & 2 & & 2 & 3840 \\
\hline Construction work & 3 & & 3 & 5.760 \\
\hline Machinery and equipment & 0 & & 0 & 0 \\
\hline All other goods and services & 7 & & 7 & 13440 \\
\hline Retail, Wholesale \& Transport industries & 11 & & 11 & 21120 \\
\hline TOTAL & 150 & 5 & 155 & 297.600 \\
\hline
\end{tabular}




\section{Macrothink}

Business and Economic Research

ISSN 2162-4860

SAE Table 4. Satellite Account for Education 4, Consumer Characteristics

2014, Vol. 4, No. 2

\begin{tabular}{|c|c|c|c|c|c|c|c|c|}
\hline \multirow[b]{2}{*}{ Characteristic Industries } & \multicolumn{2}{|c|}{$\begin{array}{c}\text { TEI } \\
\text { (total Students 862) }\end{array}$} & \multicolumn{2}{|c|}{$\begin{array}{c}\text { Education and Administrative } \\
\text { Staff } \\
\text { (total 56) }\end{array}$} & \multicolumn{2}{|c|}{ Students (862) } & \multicolumn{2}{|c|}{ Total (consumers 918) } \\
\hline & Total expend. & $\begin{array}{c}\text { Average } \\
\text { expenditure }\end{array}$ & Total expend. & $\begin{array}{c}\text { Average } \\
\text { expenditure }\end{array}$ & Total expend. & $\begin{array}{c}\text { Average } \\
\text { expenditure }\end{array}$ & Total expend. & Average expenditure \\
\hline & in $.000 €$ & in $€$ & in $.000 €$ & in $€$ & in $.000 €$ & in $€$ & in $.000 €$ & in $€$ \\
\hline Education Services of Epirus TEI (Preveza Branch) & $1.466,10$ & $1.700,81$ & & & & & $1.466,10$ & $1.700,81$ \\
\hline Rents - Amortization and Interest of housing loans & 20,00 & 23,20 & 392,94 & $7.016,81$ & $2.545,66$ & $2.953,20$ & $2.958,60$ & $2.762,46$ \\
\hline Electricity, Telecommunications, Water \& Sewage & 30,00 & 34,80 & 131,80 & $2.353,52$ & 724,08 & 840,00 & 885,88 & 827,15 \\
\hline Books & 250,00 & 290,02 & & & 121,17 & 140,57 & 371,17 & 346,57 \\
\hline Publishing services & 5,00 & 5,80 & & & & & 5,00 & 4,67 \\
\hline Conferences & 15,00 & 17,40 & & & & & 15,00 & 14,01 \\
\hline Restaurants & 250,00 & 290,02 & 70,99 & $1.267,73$ & 416,61 & 483,31 & 737,60 & 688,71 \\
\hline Food \& Beverages & & & 283,97 & $5.070,91$ & 416,61 & 483,31 & 700,58 & 654,14 \\
\hline Transportation & & & & & 422,38 & 490,00 & 422,38 & 394,38 \\
\hline Clothing - Footwear- Leather & & & 102,19 & $1.824,87$ & 369,91 & 429,13 & 472,11 & 440,81 \\
\hline Entertainment - Recreation & & & 134,10 & $2.394,63$ & 900,79 & $1.045,00$ & $1.034,89$ & 966,28 \\
\hline Repairs and Maintenance & 20,00 & 23,21 & 175,84 & $3.140,00$ & & & 195,84 & 182,86 \\
\hline Construction work & 250,00 & 290,02 & & & & & 250,00 & 233,43 \\
\hline Machinery and equipment n.e.c & 30,00 & 34,80 & & & & & 30,00 & 28,01 \\
\hline All other goods and services & & & 89,27 & $1.594,03$ & 579,52 & 672,30 & 668,79 & 624,45 \\
\hline Total consumption of all industries & $2.336,10$ & $2.710,10$ & $1.381,10$ & $24.662,50$ & $6.496,74$ & $7.536,82$ & $10.213,94$ & $9.536,83$ \\
\hline
\end{tabular}




\section{Conclusions}

This research concentrated on evaluating the economic effects of an HEI on the region hosting it. The economic impact of the Epirus TEI in the Preveza prefecture, our case study, was examined by implementing the Satellite Account methodological framework and developing four basic tables. The research findings and their implications for the Greek educational system and regional development form solid ground for the exercise of effective policy via legislative regulations and planning intervention.

Effective educational policy can increase regional income and employment without the relegation of educational benefits. The most significant contribution of this paper beyond the measurement of the real economic effects of an HEI on a prefecture or region is the ability to estimate major macroeconomic indicators accrued from the operation of an educational institution.

This study was based on data from the 2008-2009 academic year. The fluctuation of the numbers of students, as well as the fluctuation of other data such as staff and investments in parallel with the frequent changes of parameters such as VAT factors, do not permit a diachronic assessment of the impact of an educational institute but require estimation on an annual basis. The diachronic observation and estimation of the impact is suggested while other economic effects such as social, environmental and cultural effects may be included eventually.

One general conclusion of this paper is the government's ability to estimate the economic impact of every educational institute in Greece and consequently for tertiary education as a whole. The result will definitely help government and education policy-makers evaluate the efficiency and consequences of the Greek educational system and its effect on regional development.

\section{References}

Beck, R., Elliot, D., Meisel, J., \& Wagner, M. (2006). Economic Impact Studies of Regional Public Colleges and Universities. Growth and Change, 26(2), 245-260. http://dx.doi.org/10.1111/j.1468-2257.1995.tb00170.x

Berger, M. C., \& Black D. A. (1993). The Long Run Economic Impact of Kentucky Public Institutions of Higher Education. Lexington, KY: University of Kentucky Center for Business and Economic Research.

Bessette, R. W. (2003). Measuring the Economic Impact of University-Based Research. Journal of Technology Transfer, .28(3-4), 355-61. http://dx.doi.org/10.1023/A:1024917601088

Bleaney M. F., Binks M. R., Greenaway D., Reed G. V., \& Whynes D. K. (1992). What does a University add to its local economy? Applied Economics, 24(3), 305-311. http://dx.doi.org/10.1080/00036849200000143

Bluestone, B. (1993). UMASS Boston: An Economic Impact Analysis. Boston: John W. McCormack Institute of Public Affairs, The University of Massachusetts. 
Braunerhjelm P. (2008). Specialization of Regions and Universities: The New Versus the Old, Industry \& Innovation, 15(3), 253-275. http://dx.doi.org/10.1080/13662710802040853

Brown K. H., \& Heaney M. T. (1997). A note on measuring the economic impact of Institutes of higher education. Research in Higher Education, 38(2), 229-240. http://dx.doi.org/10.1023/A:1024937821040

CEC, OECD, UN, \& WTO (Commission of the European Communities, Organisation for Economic Cooperation and Development, United Nations, World Tourism Organization). (2008) Tourism Satellite Account: Recommended Methodological Framework (TSA: RMF 2008).

Cox S., \& Taylor J. (2006). The Impact of a Business School on Regional Economic Development: a Case Study, Local Economy, 21(2), 117-135. http://dx.doi.org/10.1080/02690940600608069

Di Veroli N., \& Tartamella F. (2008). Using statistics to compile an Education Satellite Account for Italy. 3rd International Symposium on Economic Theory, Policy and Applications, August 4-7, (2008) Athens, Greece

Drucker J., \& Goldstein H. (2007). Assessing the Regional Economic Development Impacts of Universities: A Review of Current Approaches. International Regional Science Review, 30(1), 20-46. http://dx.doi.org/10.1177/0160017606296731

Duke, C. (2005). The role of higher education Institutes in regional development: a report on an international seminar held at Karlstad Uni., Sweden, Oct 4-5. https://www.virtuallythere.com/new/reservationsChron.html

European Commission / Eurostat. (2008) The Bulletin of European Statistics: The economy by numbers - Focus on national accounts. Published in Sigma - 2008/03

Garlick, S. (2005) The role of higher education Institutes in regional development - the case of Australia. Paper presented at a seminar at Karlstad Uni., Sweden. https://www.oecd/longabstract

Goldstein H., \& Drucker J. (2006). The Economic Development Impacts of Universities on Regions: Do Size and Distance Matter? Economic Development Quarterly, 20(1), 22-43. http://dx.doi.org/10.1177/0891242405283387

Labrianidis L. (2010). The Greek University Stranded in the Policy of Establishing Regional Universities, European Planning Studies, 18(12), 2009-2026. http://dx.doi.org/10.1080/09654313.2010.515818

Martin F. (1998). The economic impact of Canadian university R\&D. Research Policy, 27(7), 677-687. http://dx.doi.org/10.1016/S0048-7333(98)00083-3

National Statistical Services of Greece. (2005). Symmetric Input / Output Tables

National Statistical Services of Greece. (2008). Supply and Uses Tables; Employees by economic sector Tables; GDP and GDP per capita of Greece 


\section{Macrothink}

Business and Economic Research ISSN 2162-4860 2014, Vol. 4, No. 2

OECD (Organisation for Economic Co-operation and Development). (2005). Higher Education Management and Policy: Volume 17 Issue 3 - Special Issue on Entrepreneurship: OECD Publishing,

OFFICE OF NATIONAL STATISTICS (ONS) / UK Centre for the Measurement of Government Activity. (2008). Proposals for Satellite Accounts, May 2008.

Paterson L. (2001). Higher education and European regionalism. Pedagogy, Culture \& Society, (2), 133-160. http://dx.doi.org/10.1080/14681360100200117

Quintela I. (2007). Satellite Account for Education for Portugal: Implementation process and links with the National Accounts and Questionnaire UOE. Workshop on measuring Education and Health Volume, by OECD / STATISTICS DIRECTORATE - National Accounts and Financial Statistics Division, 6 \& 7 June 2007,Château de la Muette, Paris.

Thaman K.H. (2007). The role of Higher Education in Regional Development in Pacific island countries with specific reference to the University of the South Pacific. Plenary paper, Meeting of the Asia Pacific Scientific Committee on Research in Higher Education. Sept. 17-19.

www.economics.gr. (2010). The Greek Economy in Figures. All-Media Communications.

\section{Copyright Disclaimer}

Copyright for this article is retained by the author(s), with first publication rights granted to the journal.

This is an open-access article distributed under the terms and conditions of the Creative Commons Attribution license (http://creativecommons.org/licenses/by/3.0/). 